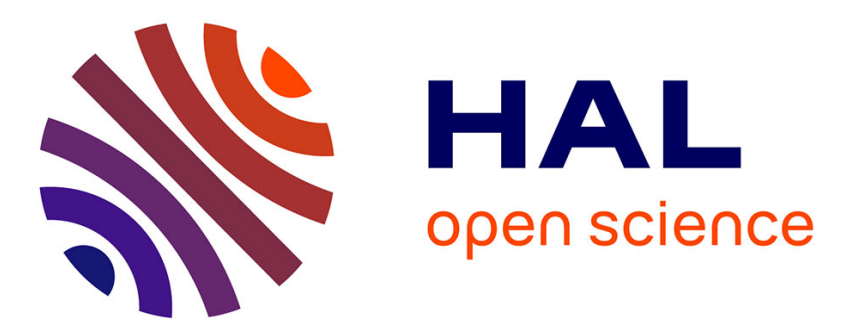

\title{
Boron Redistribution During Crystallization of Phosphorus-Doped Amorphous Silicon
}

R. Simola, Dominique Mangelinck, A. Portavoce, J. Bernardini, P. Fornara

\section{To cite this version:}

R. Simola, Dominique Mangelinck, A. Portavoce, J. Bernardini, P. Fornara. Boron Redistribution During Crystallization of Phosphorus-Doped Amorphous Silicon. AIP Conference Proceedings, 2006, 866. hal-02406692

\section{HAL Id: hal-02406692 \\ https://hal-amu.archives-ouvertes.fr/hal-02406692}

Submitted on 12 Dec 2019

HAL is a multi-disciplinary open access archive for the deposit and dissemination of scientific research documents, whether they are published or not. The documents may come from teaching and research institutions in France or abroad, or from public or private research centers.
L'archive ouverte pluridisciplinaire HAL, est destinée au dépôt et à la diffusion de documents scientifiques de niveau recherche, publiés ou non, émanant des établissements d'enseignement et de recherche français ou étrangers, des laboratoires publics ou privés. 


\title{
Boron Redistribution During Crystallization of Phosphorus- Doped Amorphous Silicon
}

\author{
R. Simola ${ }^{\text {a) }}$ D. Mangelinck ${ }^{\text {a) }}$, A. Portavoce ${ }^{\text {a) }}$, J. Bernardini ${ }^{\text {a) }}$, P. Fornara ${ }^{\text {b) }}$ \\ a) L2MP CNRS UMR 6137,case 142, Faculté des Sciences de Saint Jérôme,, 13397 Marseille cedex 13, France \\ b) ST Microelectronics, 77 avenue Olivier Perroy,13790 Rousset, France
}

\begin{abstract}
The redistribution of boron has been studied during solid phase crystallization (SPC) of a homogeneous phosphorus-doped amorphous silicon layer deposited by low pressure chemical vapor deposition, for different thermal annealing. We show that for the lower temperature annealing $\left(\mathrm{T}=586{ }^{\circ} \mathrm{C}, 1 \mathrm{~h}\right)$ boron diffuses without changing the $\mathrm{P}$ profile, while for the higher temperature annealing $\left(\mathrm{T}=800^{\circ} \mathrm{C}, 3 \mathrm{~h}\right)$, the initially homogeneous $\mathrm{P}$ profile is modified, showing two concentration peaks.
\end{abstract}

Keywords: Boron, Phosphorus, amorphous Silicon, Crystallization, Diffusion

PACS: $78.40 . \mathrm{Fy}$

\section{INTRODUCTION}

Dopant redistribution in silicon is of great importance in microelectronics. While boron diffusion has been extensively studied in crystalline silicon (c$\mathrm{Si}$ ), fewer studies exist concerning boron redistribution in poly-crystalline silicon [1-4] as well as in amorphous silicon [5-8]. In this work, we investigate the boron redistribution in a thin silicon film during a typical non volatile memory (NVM) process flow. In this process, the Si floating gate is first deposited on the $\mathrm{Si}$ oxide by low pressure chemical vapor deposition (LPCVD) as an amorphous homogeneously phosphorous-doped layer, and then implanted with boron. This layer crystallizes later in the process during the formation of the oxyde-nitride-oxyde (ONO) layer. The crystallization phenomenon is expected to greatly influence the redistribution of the dopants, and may lead to unusual variation of their concentration profiles versus the annealing time. For instance, it has been shown that both the nature of the dopant and its concentration can influence the silicon crystallization [9-10]. Furthermore, dopant diffusion depends on the crystalline state of the Si matrix, being faster in polycrystalline and amorphous $\mathrm{Si}$ than in monocrystalline $\mathrm{Si}$.

\section{EXPERIMENTAL}

The samples were made of a $100 \mathrm{~nm}$ thick amorphous $\mathrm{Si}(\mathrm{a}-\mathrm{Si})$ layer deposited by low pressure chemical vapor deposition (LPVCD) on a $12 \mathrm{~nm}$ thick $\mathrm{SiO}_{2}$ layer, which has been thermally grown on $\mathrm{Si}(001)$ substrates. The a-Si film was in-situ codeposited with phosphorous at a temperature (T) of $530{ }^{\circ} \mathrm{C}$, in order to obtain a homogeneous $\mathrm{P}$ concentration of $7 \times 10^{19}$ atoms $/ \mathrm{cm}^{3}$ in the whole layer. The a-Si film was then implanted with ${ }^{11} \mathrm{~B}^{+}$ions, with a beam energy of $7 \mathrm{keV}$ and an ion fluence of 3.5 $\times 10^{15}$ atoms $/ \mathrm{cm}^{2}$.

The samples were annealed under secondary vacuum (pressure $<10^{-6} \mathrm{mbar}$ ) at temperatures ranging from 585 to $800{ }^{\circ} \mathrm{C}$ for time between 1 and 50 hours. The temperature was measured using an in-situ thermocouple located at a few millimeters from the

samples. Transmission electron microscopy (TEM) measurements and X-ray Diffraction (XRD) measurements have shown that all the samples were polycrystalline after these different thermal treatments.

The dopant profiles were analyzed by secondary ion mass spectroscopy (SIMS). The B profiles were measured using a $3 \mathrm{keV} \mathrm{O}_{2}^{+}$primary ion beam with an incidence angle of $45^{\circ}$ while the $\mathrm{P}$ profiles were acquired under oxygen atmosphere (oxygen leak) using a $3 \mathrm{keV} \mathrm{O}_{2}{ }^{+}$primary ion beam with an incident angle of $25.2^{\circ}$.

Complementary experiments were performed in order to estimate the crystallization time (time which 
is needed to completely crystallize the a-Si layer at a given temperature). In-situ XRD measurements were performed on a-Si undoped, phosphorus-doped and boron-doped layers made following the same process as previously described. During isothermal annealing at $\mathrm{T}=565{ }^{\circ} \mathrm{C}$ under vacuum $\left(\mathrm{p}<10^{-4}\right.$ mbar $)$, the variations of the (111)Si X-ray peak intensity was recorded versus time, in the classical Bragg-Brentano geometry. The temperature was monitored using a thermocouple in contact with the surface of the samples.

\section{RESULTS AND DISCUSSION}

The boron concentration profiles measured before and after a low temperature thermal annealing ( $1 \mathrm{~h}$ at $585{ }^{\circ} \mathrm{C}$ ) are shown in Fig. 1. Despite an annealing at low temperature, a non negligible part the B atoms did diffuse and an additional shoulder appear on the profile.

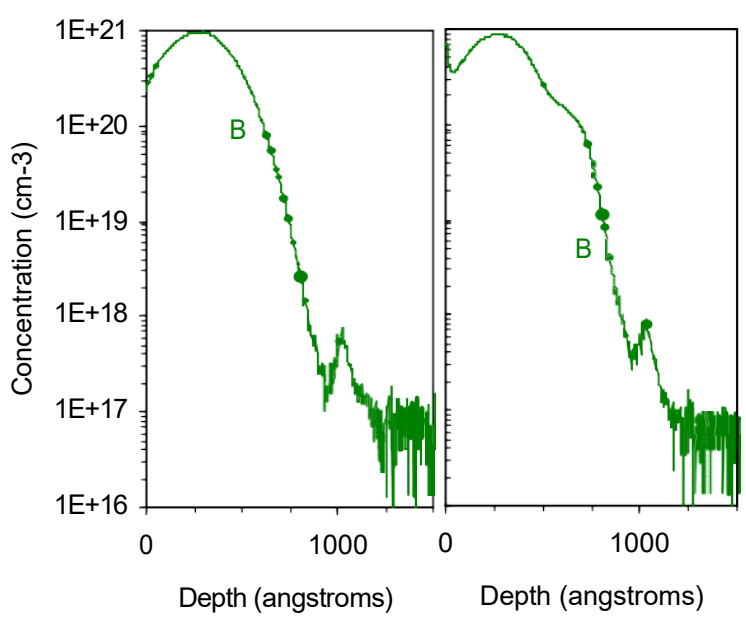

FIGURE 1: Boron profile measured by SIMS, before thermal annealing (left) and after $\mathrm{T}=585^{\circ} \mathrm{C} 1 \mathrm{~h}$ annealing (right).

One can clearly observe on Fig. 1 that this shoulder located in the region between $50 \mathrm{~nm}\left(\mathrm{C}_{\mathrm{B}}=2 \times 10^{20}\right.$ $\left.\mathrm{cm}^{-3}\right)$ and $70 \mathrm{~nm}\left(\mathrm{C}_{\mathrm{B}}=8.5 \times 10^{19} \mathrm{~cm}^{-3}\right)$ is followed by an abrupt slope which ends at a depth of $\sim 94 \mathrm{~nm}$ $\left(\mathrm{C}_{\mathrm{B}}=4 \times 10^{17} \mathrm{~cm}^{-3}\right)$. The peak at a depth of $\sim 100$ $\mathrm{nm}$, located in the $\mathrm{SiO}_{2}$ layer zone, is certainly a SIMS artifact due the so-called matrix effect [11], which originates here from a higher ionization rate of $\mathrm{B}$ atoms in the $\mathrm{SiO}_{2}$ matrix compared to the Simatrix.
It is important to notice that for these experiments the concentration of boron in the as-implanted sample is notably higher than the boron solubility limit in monocrystalline $\mathrm{Si}\left(\sim 4 \times 10^{17} \mathrm{~cm}^{-3}\right.$ at $\left.600{ }^{\circ} \mathrm{C}[12]\right)$. Thus the fact that a part of the $\mathrm{B}$ atoms did not diffuse can be explained considering that during the annealing the immobile atoms formed boron-interstitial-clusters (BICs), whose properties have been the object of theoretical [13-15] and experimental [16-20] studies.

Fig. 1 shows that boron atoms which have diffused during the thermal treatment correspond to a concentration lower than $2 \times 10^{20} \mathrm{~cm}^{-3}$, which is higher than the common solubility limit of $\mathrm{B}$ in c-Si at $600{ }^{\circ} \mathrm{C}$. This higher value can be understood considering that atoms could have diffused while the layer was still amorphous. In this case the solubility limit of $\mathrm{B}$ is expected being higher than in c-Si (a-Si has a lower density than c-Si [21]) and is not precisely known as it may depend on the nature of the amorphous layer. Also, it has been shown that in the case of implanted pre-amorphized $\mathrm{Si}$ layer the solubility of B can be greatly increased after solid phase epitaxial crystallization $\left(3.5 \times 10^{20} \mathrm{~cm}^{-3}\right.$ in the temperature range $\mathrm{T}=800-1000{ }^{\circ} \mathrm{C}$ [22] and up to $2 \times$ $10^{20} \mathrm{~cm}^{-3}$ in the low-temperatures range $\mathrm{T}=500-600^{\circ} \mathrm{C}$ [7] ). The same mechanism can take place in our experiments.

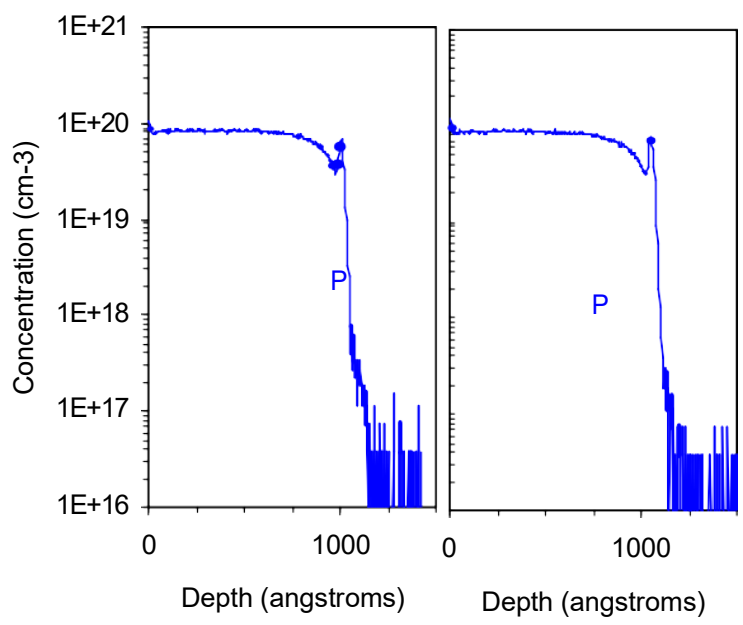

FIGURE 2: Phosphorus profile measured by SIMS, before thermal annealing (left) and after $\mathrm{T}=585^{\circ} \mathrm{C} 1 \mathrm{~h}$ annealing (right).

The width of the extra-shoulder observed on the SIMS profile measured after annealing can be considered as the diffusion length of the B atoms 
during the treatment. It is about $20 \mathrm{~nm}$. This distance is somewhat greater than the one expected for boron diffusion in polycrystalline $\mathrm{Si}$ (poly-Si), as according to [2] this distance should be only of $\sim 7 \mathrm{~nm}$ for our annealing conditions. This may be explained by a faster diffusion of boron in a-Si.

Furthermore, the abrupt slope observed after the shoulder (depth greater than $70 \mathrm{~nm}$ ) cannot be simulated with a diffusion model using a constant diffusion coefficient (even if the presence of boron clusters is considered). Different phenomena that could explain this abrupt slope include a concentration dependence of the boron diffusion coefficient and/or the influence of the mobile interface between the amorphous and the crystalline parts of the $\mathrm{Si}$ layer during the crystallization.

Figure 2 shows that the phosphorus profile is found unchanged after the lower temperature annealing $(\mathrm{T}=$ $\left.585^{\circ} \mathrm{C}, 1 \mathrm{~h}\right)$. This is what is reasonably expected in the case of a homogeneous material, as the SIMS profile of phosphorus does not present any concentration gradient. Neither the presence of boron, nor the crystallization is thus found having a significant effect on the phosphorus distribution.

As already cited, at sufficient high temperatures crystallization of doped a-Si takes place relatively quickly. Normalized (111)Si X-ray diffraction peaks $\left(2 \theta=28.4^{\circ}\right)$ for undoped a-Si (250 nm-thick), phosphorus-doped a-Si (150 nm-thick) and boron implanted a-Si (250 nm-thick) as a function of annealing time are shown in Fig. 3 . All the samples where annealed at $\mathrm{T}=565^{\circ} \mathrm{C}$.

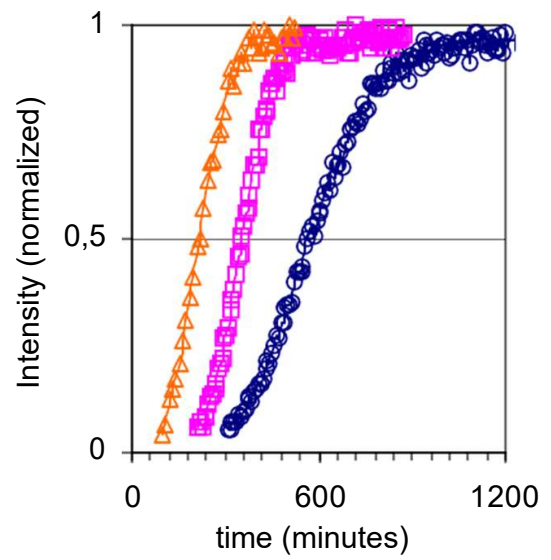

FIGURE 3: XRD normalized peaks for non doped (circle), phosphorus doped (triangle) and boron doped (square) a-Si films, as a function of annealing time at $\mathrm{T}=565^{\circ} \mathrm{C}$.
In all three cases, the intensity peak does not start to increase immediately; it takes some time, a latent time, for crystallization to start. This latent time is maximum for undoped a-Si and minimum for the phosphorusdoped a-Si film. The phosphorus doped a-Si sample is the fastest to crystallize; total time for crystallization is about 360 minutes at $\mathrm{T}=565{ }^{\circ} \mathrm{C}$. At higher temperatures, crystallization time should be much shorter because of the exponential dependence of crystallization rate on temperature. Through these measurements we were able to: i) confirm that boron and phosphorus enhance crystallization; ii) set a lower bound for crystallization time for all the experiments that we have performed.

Figure 4 shows the boron (left) and the phosphorus (right) profiles measured after annealing at $650{ }^{\circ} \mathrm{C}$ for 50 hours. In contrast with the previous annealing $(\mathrm{T}=$ $585{ }^{\circ} \mathrm{C}, 1 \mathrm{~h}$ ) diffusion in poly-Si cannot be neglected anymore [2]. As the $\mathrm{Si}$ film is found being polycrystalline after a thermal treatment at $585^{\circ} \mathrm{C}$ for 1 hour, it is reasonable to consider that at $650{ }^{\circ} \mathrm{C}$ for 50 hours the crystallization is faster (diffusion in the a-Si is shorter), and thus boron atoms diffuse in a poly-Si matrix during at least 49 hours. The boron profile, at a depth below $70 \mathrm{~nm}$ is found to be similar to the one obtained during the lower temperature annealing.

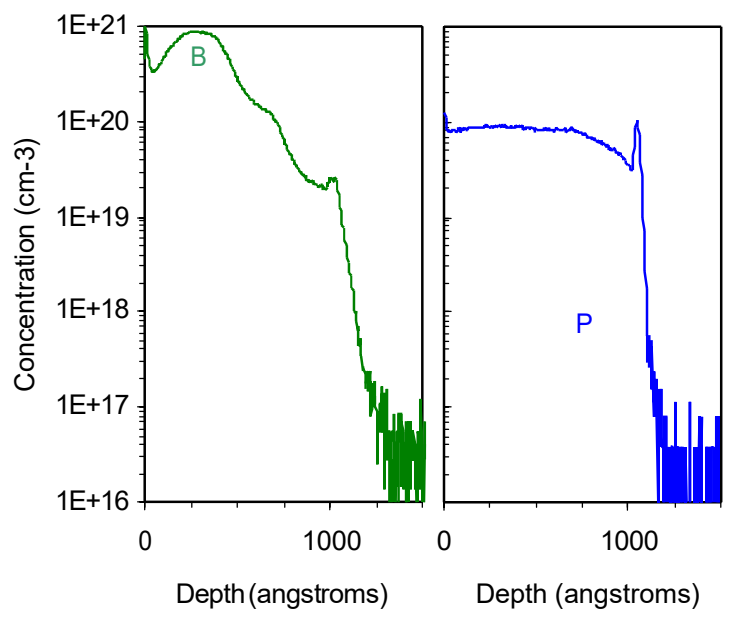

FIGURE 4: Boron (left) and phosphorus (right) profiles after $\mathrm{T}=650^{\circ} \mathrm{C} 50 \mathrm{~h}$ thermal annealing.

The significant changes in the boron profile, compared to the boron profile obtained after annealing at $585{ }^{\circ} \mathrm{C}$ for 1 hour, start from a depth of $70 \mathrm{~nm}$ with a concentration about $\mathrm{C}_{\mathrm{B}}=1 \times 10^{20} \mathrm{~cm}^{-3}$. We 
conclude that the left part of the profile (depth below $70 \mathrm{~nm}$ ) is mainly due to the boron redistribution before and during crystallization, while for greater depth the concentration profile of boron results from the diffusion of atoms in poly-Si. Boron solubility limit in phosphorus-doped poly-Si seems thus to be $1 \times 10^{20}$ $\mathrm{cm}^{-3}$ consistent with the previous study [13]. The right-hand phosphorus profile in Fig. 4, shows an almost constant concentration after the annealing, with small variations at depth around $33 \mathrm{~nm}$ and $70 \mathrm{~nm}$ where little local maxima appeared.

High-temperature crystallization annealing $\left(\mathrm{T}=800^{\circ} \mathrm{C}, 5 \mathrm{~h}\right)$ results are shown in Fig. 5 for boron (left) and phosphorus (right). Boron profile is quite flat between $75 \mathrm{~nm}$ and $94 \mathrm{~nm}\left(\mathrm{C}_{\mathrm{B}}=1.2 \times 10^{20} \mathrm{~cm}^{-3}\right.$ and $9.3 \times 10^{19} \mathrm{~cm}^{-3}$ respectively) due to boron diffusion in polycrystalline silicon. The rest of the profile, namely for depth below $70 \mathrm{~nm}$, is similar to the one obtained after low-temperature annealing $\left(\mathrm{T}=585^{\circ} \mathrm{C}, 1 \mathrm{~h}\right)$ despite a significant change in the $30 \mathrm{~nm}$ peak which concentration diminished and reached the value of $6 \times 10^{20} \mathrm{~cm}^{-3}$ We conclude that at $\mathrm{T}=800^{\circ} \mathrm{C} 5 \mathrm{~h}$, boron diffusion length in polycrystalline is about $20 \mathrm{~nm}$. Atomic Force Microscopy measurements (not shown in this paper) yield an average diameter of $40 \mathrm{~nm}$ for the grains. Phosphorus profile displays two concentration peaks at $30 \mathrm{~nm}$ and $70 \mathrm{~nm}$; since concentration profile is constant before annealing, these peaks are certainly due to boron-phosphorus interactions; such interaction may include electrical and/or chemical ones.

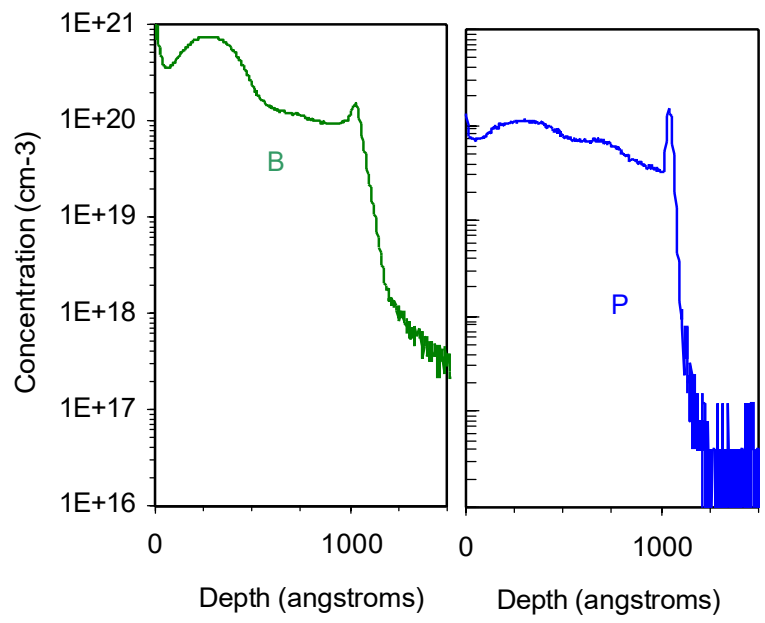

FIGURE 5: Boron (left) and phosphorus (right) profiles after $\mathrm{T}=800^{\circ} \mathrm{C} 5 \mathrm{~h}$ thermal annealing

\section{ACKNOWLEDGMENTS}

The authors would like to thank K. Hoummada for the help concerning the XRD measurements.

\section{REFERENCES}

1. T.I. Kamins, J. Manoliu, R.N. Tucker, Tucker, J. Appl. Phys. 43, 83 (1972)

2. K.Sakamoto, K. Nishi, T. Yamaji, T. Miyoshi and S. Ushio, J. Electrochem. Soc. 132, 2457-2462 (1985)

3. A. Merabet, C. Gontrand, Mat. Science and Eng. B102, 257-261 (2003)

4. B. Semmache, A. Merabet, C. Gontrand, A. Laugier, Mat. Science and Engin. B38, 41 (1996)

5. J. M. Jacques, L.S. Robertson, K.S. Jones, Appl. Phys. Lett. 82, 3469-3471 (2003)

6. R. Duffy, V.C. Venezia, A. Heringa, T.W.T. Husken, M.J.P. Hopstaken, N.E.B Cowern, P.B. Griffin, C.C. Wang, Appl. Phys. Lett. 82, 3647-3649 (2003)

7. R. Duffy, V.C. Venezia, A. Heringa, B.J. Pawlak, M.J.P Hopstaken, G.C.J Maas, Y. Tamminga, T. Dao, F. Roozeboom, L. Pelaz, Appl. Phys. Lett. 84, 4283-4285 (2004)

8. V.C. Venezia, R. Duffy, L. Pelaz, M.J.P Hopstaken, G.C.J. Maas, T. Dao, Y. Tamminga, P. Graat, Mat. Science and Engin. B124-125, 245-248 (2005)

9. R. Bisaro, J. Magarino, K. Zellama, S. Squelard, P. Germain, J.F. Morhange, Phys. Rev. B 31, 3568-3575 (1985)

10. H-C. Cheng, F-S. Wang, Y-F. Huang, C-Y. Huang, J. Electrochem. Soc.142, 3574-3578 (1995)

11. V. R. Deline, William Katz, C. A. Evans, Jr., and Peter Williams, J. Appl. Phys. 33, 832 (1978)

12. P. Pichler, Mat. Res. Soc. Symp. Proc. 717, 103 (2002)

13. L. Pelaz, M. Jaraiz, G. H. Gilmer, H.-J. Gossmann, C.S. Rafferty, D. J. Eaglesham, and J. M. Poate, Appl. Phys. Lett. 70, 2285 (1997)

14. X.-Y. Liu, W. Windl, and M. P. Masquelier, Appl. Phys Lett. 77, 2018 (2000)

15. P. Alippi, P. Ruggerone, L. Colombo, Phys. Rev. B 69, 125205 (2004)

16. G. Mannino, N. E. B. Cowern, F. Roozeboom, J. G. M. van Berkum, Appl. Phys. Lett. 76, 855 (2000)

17. A. D. Lilak, M. E. Law, L. Radic, K. S. Jones, M. Clark, Appl. Phys. Lett. 81, 2244 (2002)

18. S. Mirabella, E. Bruno, F. Priolo, D. De Salvador, E. Napolitani, A. V. Drigi, A. Carnera, Appl. Phys. Lett. 83, 680 (2003)

19. A. M. Piro, L. Romano, S. Mirabella, M. G. Grimaldi, Appl. Phys. Lett. 86, 81906 (2005)

20. L. Romano, A. M. Piro, S. Mirabella, M. G. Grimaldi, E. Rimini, Appl. Phys. Lett. 87, 201905 (2005)

21. J.S. Custer, M.O. Thompson, D.C. Jacobson, J.M. Poate, S. Roorda, W.C. Sinke, F. Spaepen, Appl. Phys. Lett. 64, 437-439 (1994)

22. S. Solmi, E. Landi, F.Baruffaldi, J. Appl. Phys. 68, 3250 (1990) 